\title{
Promoting Public Awareness of Carbon Capture and Storage Technologies in the Russian Federation: A System of Educational Activities
}

\author{
Yurii Vasilev ${ }^{1}$, Alexey Cherepovitsyn ${ }^{1} \mathbb{D}$, Anna Tsvetkova ${ }^{1} \mathbb{D}$ and Nadejda Komendantova ${ }^{2, *}$ \\ 1 Department of Economics, Organization and Management, Saint Petersburg Mining University, 2, 21st Line, \\ 199106 Saint Petersburg, Russia; Vasilev_YuN@pers.spmi.ru (Y.V.); Cherepovitsyn_AE@pers.spmi.ru (A.C.); \\ Tsvetkova_AYu@pers.spmi.ru (A.T.) \\ 2 International Institute for Applied Systems Analysis (IIASA), Schlossplatz 1, A-2361 Laxenburg, Austria \\ * Correspondence: komendan@iiasa.ac.at
}

check for

updates

Citation: Vasilev, Y.; Cherepovitsyn, A.; Tsvetkova, A.; Komendantova, N. Promoting Public Awareness of Carbon Capture and Storage Technologies in the Russian Federation: A System of Educational Activities. Energies 2021, 14, 1408. https://doi.org/10.3390/ en14051408

Academic Editor:

Nikolaos Koukouzas

Received: 30 January 2021

Accepted: 27 February 2021

Published: 4 March 2021

Publisher's Note: MDPI stays neutral with regard to jurisdictional claims in published maps and institutional affiliations.

Copyright: (c) 2021 by the authors. Licensee MDPI, Basel, Switzerland. This article is an open access article distributed under the terms and conditions of the Creative Commons Attribution (CC BY) license (https:/ / creativecommons.org/licenses/by/ $4.0 /)$.
Abstract: The latest technologies for climate change mitigation are carbon capture and storage (CCS) Some countries are developing CCS projects, and they are currently at different stages of deployment. Despite the signing of international agreements on climate change mitigation, Russia's efforts to develop and implement CCS technologies are quite limited. Therefore, it is vital that people are aware of the importance of carbon dioxide capture, utilization, and storage. The purpose of this article is to produce guidelines and toolkits to form a system of measures aimed at raising awareness of the Russian society on carbon dioxide capture and storage technologies. The paper discusses the key findings of several recent studies on the topic, e.g., a study focusing on the level of environmental consciousness among St. Petersburg students; a content analysis of the Russian school textbooks; a study of environmental groups in Russian social media; and an experimental study on creating eco-comics and posters as educational tools for promoting environmental awareness. A multi-level system of educational activities is proposed, including events for preschoolers, schoolchildren, students, and adults.

Keywords: carbon storage; public attitude; public awareness; sequestration; carbon dioxide; CCStechnologies

\section{Introduction}

To date, the main objective of climate conservation is to reduce greenhouse gas emissions (GHG) while maintaining the growth rate of living standards, industry and economy. The main ways of reducing GHG emissions are the following [1-5]:

- energy consumption decrease and energy efficiency technology increase;

- transition from non-renewable energy to renewable one;

- replacement of fuel types in power industry (transition from coal to gas);

- carbon dioxide capture and storage (CCS technology).

Carbon capture and storage is widely seen as a critical strategy for limiting atmospheric emissions of carbon dioxide-the principal "greenhouse gas" linked to global climate change-from power plants and other large industrial sources [3]. The special technologies provide $\mathrm{CO}_{2}$ capture from the atmosphere (air capture). They can be also installed at power plants, oil refineries, or chemical plants. The target of $\mathrm{CO}_{2}$ capture is to form carbon captured currents for transporting it to its storage [6,7].

The five main types of geological storage of carbon dioxide can be identified [3,5,7]:

- depleted oil and gas reservoirs;

- un-minable coal beds;

- $\quad$ in deep saline formations;

- water-bearing strata; 
- ocean bottom storage.

Currently carbon capture technologies evolve rapidly and provide [3,7-10]:

- carbon dioxide capture after fuel combustion;

- carbon dioxide capture during oxy-fuel combustion;

- carbon dioxide capture before fuel combustion;

- membrane capture technologies;

- carbon dioxide capture using chemical processes.

The 23rd Conference of the UN on climate change, on 6-17 November 2017, proved the relevance of using CCS technologies. The conclusion was drawn that it is necessary to double decrease in $\mathrm{CO}_{2}$ emissions in the atmosphere every 10 years. According to the forecast, the contribution of CCS technologies in decreasing global $\mathrm{CO}_{2}$ accumulation will be at least $13 \%$ by 2050 [11].

In the case of decarbonization commitments, the noticeable place is taken by the technologies of $\mathrm{CO}_{2}$ sequestration. The International Energy Agency (Paris, France) and the UN International Panel on Climate Change (Geneva, Switzerland) recognize that without public large-scale information spreading about these technologies, emission reduction targets are not possible to attain [6]. The CCS projects provide a flexible transition to emission reduction. Unlike more radical decarbonization mechanisms (non-use of fossil fuels, switching to green energy, etc.), they do not require replacing global infrastructure and support industries, thereby preserving jobs and tax revenues [6].

Despite positive assessments of the CCS technologies efficiency, the number of existing projects is currently limited. According to the Global CCS Institute (Melbourne, Australia), there are presently 51 large-scale CCS projects worldwide [12]. Today more than 30 countries across the world deploy or plan to deploy about 300 carbon capture and storage projects [1]. Most of the current projects are localized in the USA and Canada [13]. Currently in the Russian Federation there are no projects of $\mathrm{CO}_{2}$ sequestration even at the early-stage of planning.

Both creating robust financial incentives and public approval can greatly contribute to the further development of CCS technologies. Public awareness of necessity to reduce GHG emissions is an important initial condition to create climate protection system at the national level [14].

We define public awareness as a certain level of public knowledge concerning a particular problem, phenomenon, or activity. Public awareness is a prerequisite for public acceptance. Public approval is regarded as a certain informal authorization for any activity [15]. Australian scientists propose the term "social license to operate" (SLO), which involves the social aspects for planning development of such technologies [16].

In 2015, the UN drafted the resolution on sustainable development adoption "Transforming our world: The agenda 2030 for Sustainable Development". The paper established 17 sustainable development goals including 169 associated targets which are designed for stimulating initiative, monitoring performance, and levering compliance. With regard to our research, it is worth emphasizing Goal 13:"Take urgent actions to combat climate change and its impacts". One of the targets for achievement is the following: "Improve education, awareness-raising and human and institutional capacity on climate change mitigation, adaptation, impact reduction and early warning".

Thus, the spread of CCS technologies directly depends on the public approval of these technologies. For instance, Ferguson stresses that community acceptance is as vital to success as the physical and infrastructure elements of any CCS project [17]. Whereas the degree of public approval is determined by the level of public awareness on this issue (Figure 1). 


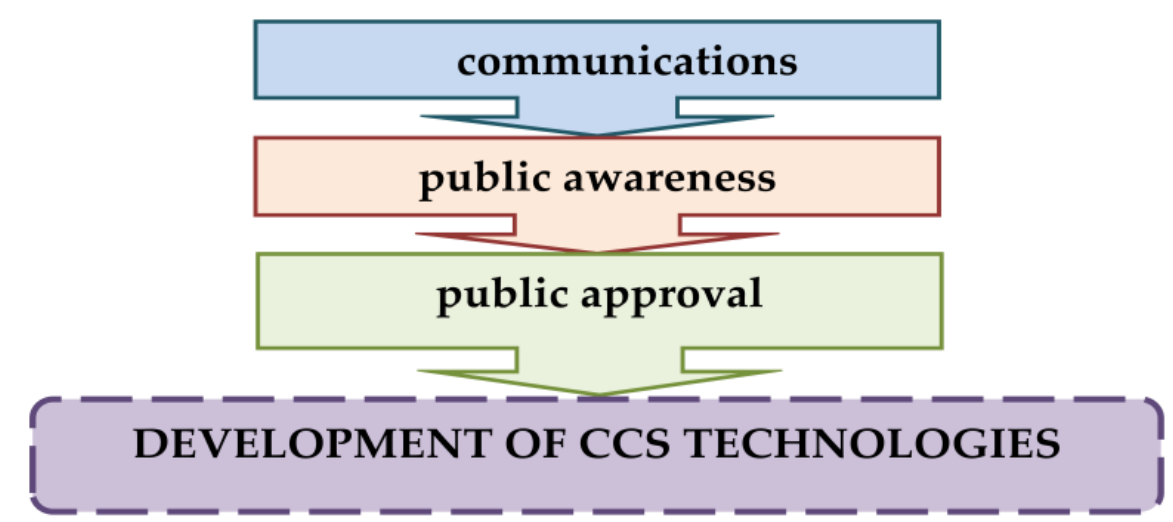

Figure 1. Social factors of CCS-technologies development. Source: authors self-elaboration.

To improve public awareness on CCS technologies it is necessarily to provide continuous communications flow [18].

In a number of developed and developing countries (Australia, India, Indonesia, USA, Japan) the research is being carried out on the social issues of building communication system to shape public opinion on implementation of CCS technologies [19-27]. There are some studies considering public impact of newspapers [14,28], videos [29], social networks [30], other media [17], as well as a comparison of online and offline communications regarding CCS technologies [31].

Table 1 gives an overview of the research results on global public awareness of carbon capture and storage technologies.

Table 1. Review of research results on public awareness of carbon capture and storage technologies.

\begin{tabular}{|c|c|c|}
\hline Country, Year & Type of Research & Research Results \\
\hline Japan, 2015 & Polling survey & $\begin{array}{l}\text { More than } 50 \% \text { of respondents do not know about } \\
\text { CCS-projects at all; about } 40 \% \text { of them have heard the word; } \\
7 \% \text { know it; } 3 \% \text { know well and can explain. }\end{array}$ \\
\hline $\begin{array}{l}\text { Japan, } \\
2010,2013,2015\end{array}$ & $\begin{array}{l}\text { Internet survey of more than } \\
20 \text { thousand respondents }\end{array}$ & $\begin{array}{l}\text { More than } 50 \% \text { of respondents do not know about } \\
\text { CCS-projects at all; more than } 30 \% \text { of them have heard the } \\
\text { word; about } 10 \% \text { of respondents know well and can explain }\end{array}$ \\
\hline PRC, 2013 & Survey of 563 respondents & $\begin{array}{l}26.7 \% \text { of respondents do not know about CCS-projects at all; } \\
22.9 \% \text { - know it; } 44 \% \text { have heard the word; } 6.1 \% \text { know well }\end{array}$ \\
\hline Romania & $\begin{array}{l}\text { Survey of more than } \\
1000 \text { thousand respondents }\end{array}$ & $\begin{array}{l}\text { More than } 75 \% \text { of respondents do not know about } \\
\text { CCS-projects at all }\end{array}$ \\
\hline $\begin{array}{l}\text { Australia, Japan and the } \\
\text { Netherlands } 2012\end{array}$ & Survey of 2470 respondents & $\begin{array}{l}\text { Respondents from Australia demonstrated quite low level of } \\
\text { knowledge of } \mathrm{CO}_{2} \text { properties, uses and effects. } \\
\text { Japanese respondents revealed the highest level of } \\
\text { appropriate knowledge. } \\
\text { Respondents from the Netherlands displayed the lowest level. }\end{array}$ \\
\hline
\end{tabular}

Source: Designed by authors using [26,32-35].

According to the data presented in Table 1, the level of public awareness of CCS technologies in different countries of the world is quite low. We can observe the highest level of public consciousness only in those countries where carbon capture and storage projects are currently being implemented. Unfortunately in the Russian Federation the level of public awareness is low.

To build an effective communication system regarding any matter of social concern, it is necessary to identify key stakeholders whose interests are tightly connected with this problem. The researchers dealing with the issues related to informing major stakeholders regarding CCS projects have developed the communication structure depending on the level of the stakeholder. For different stakeholders, different types of communications are recommended $[17,31,36,37]$. 
It should be stated that in the Russian Federation the public perception of global warming has not been shaped [38], despite the visible signs of this phenomenon (more than 3 degrees increase in the average winter season temperature in the Russian Arctic zone, a snow and ice cover decrease, the risk of flooding coastal areas, etc.) [39].

For the last few years the Russian scientists have been paying more and more attention to studying public perception on implementing CCS projects [40-43].

Thus, A. E. Cherepovitsyn et al. [44] proposed a typology of incentive tools for promoting carbon dioxide capture and storage technologies, in particular, including a number of public events. He distinguished such activities as public promotion of environmental technologies; transmission of environmental knowledge to future generations for controlling and preventing possible negative consequences. E. A. Telegina and D.O. Tyrtyshova [45] emphasize the links between socio-political support for decarbonization and long-term prospects for using natural gas in the market.

The purpose of the paper is to make recommendations for building an integrated system of educational toolkits to improve public awareness on carbon dioxide capture and storage technologies in the Russian Federation.

\section{Materials and Methods}

To develop a communication system, it is necessary to investigate the value of various information sources for different focus groups in Russia.

According to the studies regarding the popularity of various media channels among Russian citizens [46], the key source of information for residents over 18 years old is news, analytical and official sites on the Internet. Additionally, television is popular among citizens of all age groups. At the same time, it should be noted that the older respondents are, the more valuable television is. The social networks and blogs occupy the third place of popularity, but for the elderly the importance of these sources is not very high.

The number of daily radio listeners is $25 \%$ of respondents, and the same percentage of citizens listens to the radio once or more times a week in the Russian Federation. There is a new tendency among the youngest audience to displace television and radio by internet sites and social networks. The highest proportion of the global network users are schoolchildren and students (60\%). In Russia, about $45 \%$ of people in the age group 25-39 and $25 \%$ of people in the age group $45-54$ use the Internet on a daily basis [46].

The value of print media is a debatable and controversial issue. So, according to Deloitte [46], print media are the least popular news sources. Whereas, according to the survey conducted by the All-Russian Public Opinion Research Center (VTsIOM) (Moscow, Russia), more than $70 \%$ of Russian respondents prefer to read print newspapers and magazines [47].

We assume that such variation of findings could be due to different proportions of age groups in the samples. Respondents under the age of 25 do not consider print newspapers and magazines as a source of information but receive information mainly from the Internet. While, for people from the other age groups, print media are more significant.

To develop guidelines and toolkits for improving public awareness of CCS technologies, it is necessary to take into account the study results of the value of media resources in the Russian society. The key internet resources are social networks, news portals, and photo and video hosting. Table 2 shows the popularity of various media resources in the Russian Federation.

Table 2. Popularity of Internet sources among age groups, $\%$.

\begin{tabular}{|c|c|c|c|c|c|c|}
\hline \multirow{2}{*}{ Internet Source } & \multicolumn{6}{|c|}{ Age Groups, \% } \\
\hline & $16-24$ & $25-34$ & $35-44$ & $45-54$ & $55-64$ & $>64$ \\
\hline VKontakte & 91 & 86 & 66 & 60 & 52 & 44 \\
\hline YouTube & 73 & 62 & 58 & 60 & 64 & 60 \\
\hline Odnoklassniki & 17 & 31 & 49 & 48 & 56 & 56 \\
\hline Online news outlets & 13 & 24 & 33 & 38 & 37 & 51 \\
\hline Instagram & 61 & 38 & 17 & 12 & 8 & 1 \\
\hline Facebook & 8 & 15 & 23 & 27 & 35 & 34 \\
\hline
\end{tabular}


Table 2 shows that social networks VKontakte and Instagram are the most popular among people aged 16-43 years old, while the social network Odnoklassniki gains its popularity only among the age group of 45-65 years old. Respondents under the age of 35 show little regard for Facebook, whereas elderly age groups neglect Instagram. YouTube video hosting is equally popular among all age groups.

Undoubtedly, social networks and video hosting play a crucial role for promoting public awareness of any issues in the Russian Federation.

We analyzed the popularity degree of different types of mass media among Russian students to produce guidelines for forming national educational tools. The study was carried out in the form of students' survey of two universities in St. Petersburg: St. Petersburg Mining University and St. Petersburg University (St. Petersburg, Russia). It was conducted from 1 September 2020 to 1 October 2020. In total, more than 200 students took part in the survey. The questionnaire consisted of 17 factual questions about climate change (CC). The survey focused on identifying the respondents' awareness of climate change and reveal contemporary public perception concerning global warming.For example, the polled students were offered a list of environmental issues and asked to circle the three issues that concerned them the most. They were also asked to give a brief explanation of climate change, its causes and effects, and how they could tackle it. Moreover, the respondents answered the questions about their information sources and trust in Media sources related to CC. One of the questions was referred to students regular based activities to mitigate global warming. As the survey was conducted after experimental case study, the question about the most effective educational tools and approaches was also included.

In terms of our paper, we analyzed the respondents' answers concerning the sources of getting information about climate change.

To provide interdisciplinary environmental research, we conducted an experimental case study introducing an environmental component to the English for the Media course offered at St. Petersburg University (School of Journalism and Mass Communications). As we highlight the crucial role of Media in the shaping of the public consciousness of climate change, students of journalism were proposed to do a creative environmental project entitled "Public environmental awareness through eco-comics". After having read texts related to environmental issues, watched YouTube videos explaining the causes and effects of climate change, and discussed how the students could contribute to climate change mitigation on a daily basis, they were encouraged to design eco-comics and posters to be co-creators of interdisciplinary environmental journalism studies in English and environmental awareness campaigns (see Figures 2 and 3). According to the results, eco-comics are lightweight, exciting, and effective educational tools for raising public environmental awareness.
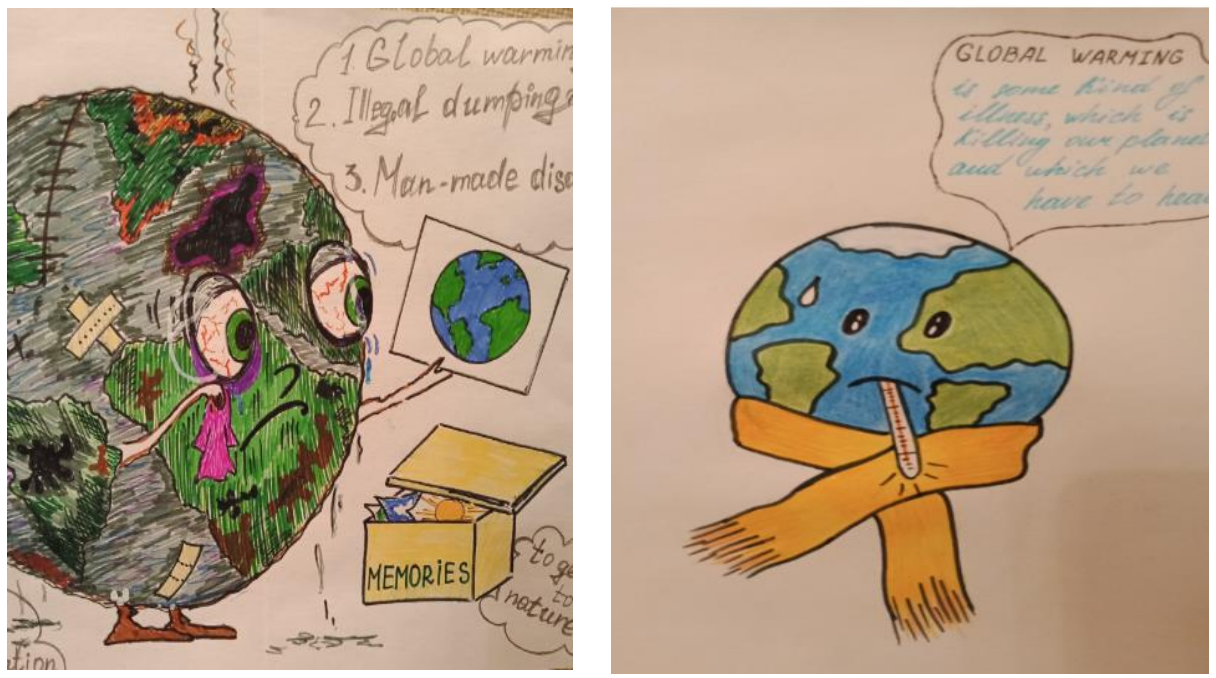

Figure 2. Poster projects on environmental issues. 

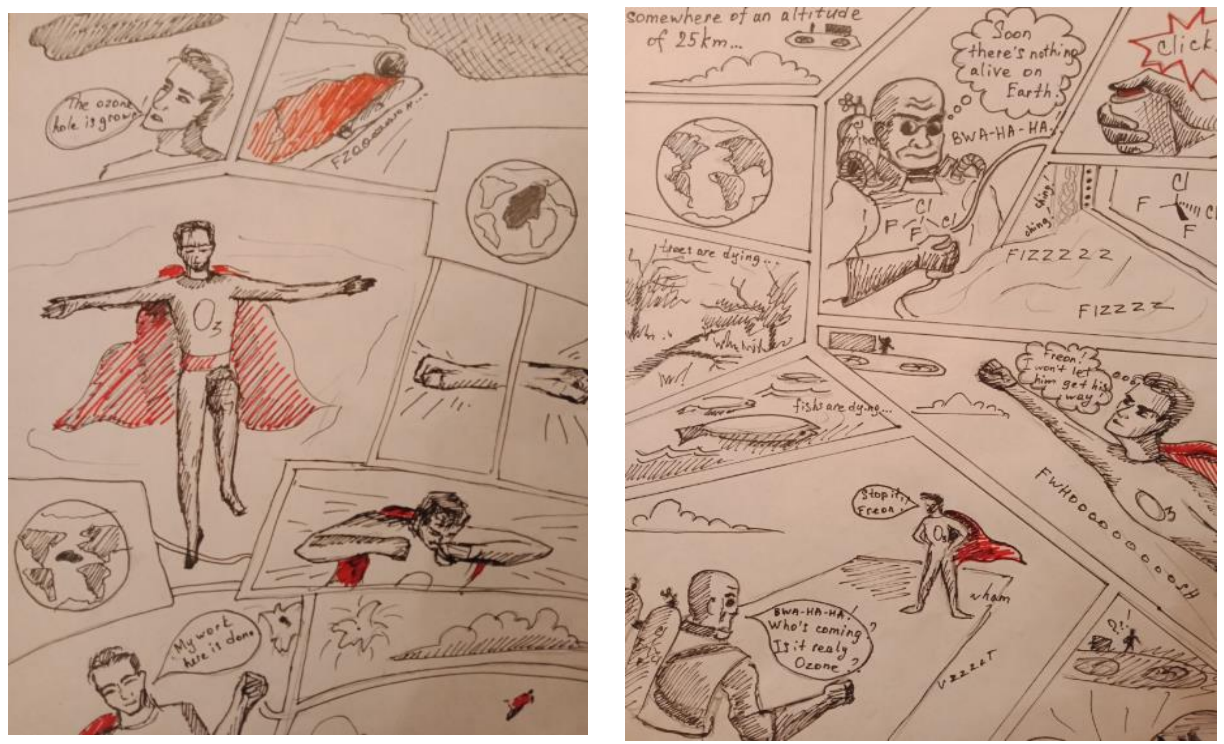

Figure 3. Environmental comics created by students.

In order to achieve the objectives of the paper, the Russian school textbooks were also analyzed to detect information on environmental topics, in particular, references to the need of reducing greenhouse gases emissions and the technologies of how to do it.

Besides this, a secondary study of newspaper articles published in the Russian Federation over 10 years was conducted from 1 January 2010 to 31 December 2019. The study was based on the most rated national newspapers such as: Argumenty i Facty, Vedomosti, Gazeta.ru, Zhizn, Izvestia, Kommersant, Komsomolskaya Pravda, Kultura, Metro, Moskovsky Komsomolets, Moya Semya, Novaya Gazeta, Rossiyskaya Gazeta, Sovershenno sekretno.

The study was conducted by searching for publications on the official newspapers websites using such keywords as $\mathrm{CO}_{2}$, carbon dioxide, CCS. All types of publications (papers, announcements, interviews, news, etc.) were observed.

The study considered publications on $\mathrm{CO}_{2}$ emission reduction, climate changes regarding $\mathrm{CO}_{2}$ concentration increase, technologies for reducing $\mathrm{CO}_{2}$, etc. Publications dedicated to the production of new car models with a reduced $\mathrm{CO}_{2}$ emission rate, electric vehicles, separate waste collection, pharmaceuticals, and agriculture were not observed. The research did not focus on publications that cited $\mathrm{CO}_{2}$ information to support the main topic of the article.

Video hosting materials and YouTube were also investigated by the request of "Carbon capture and storage" to identify videos on the topic. The most popular Russian social networks VKontakte, Facebook, and Odnoklassniki were also observed.

\section{Results and Discussion}

The sociological study on environmental awareness among students of two universities in St. Petersburg (St. Petersburg Mining University and St. Petersburg University) revealed the three most popular sources of information. The first one is internet sources $(86 \%)$, the second source is university knowledge obtained from academic disciplines $(73 \%)$, and then television (71\%). The least popular are radio and newspapers (13 and $8 \%$, respectively). It is also noteworthy that more than $20 \%$ of respondents do not find the issue of climate change personally important to them at all.

In this regard publications on the Internet, television shows, as well as information from academic training courses can be considerably efficient for raising awareness among the Russian student community. Unfortunately, radio broadcasts and print media are not so sufficient tool for improving environmental consciousness among students. 
As we have mentioned above, students can also be involved in promoting public environmental awareness. The eco-comics experiment case study showed that many students of journalism were highly motivated and inspired to be involved in the inquirybased learning process. As a result, they created amazing eco-comics and posters in different genres. Some of them are given in Figures 2 and 3.

Thus, creation of eco-comics and posters prove our research hypothesis that they are an effective educational toolkit for raising environmental consciousness among schoolchildren and students on the issues of environmental protection and CCS technology.

It is noteworthy that the keen interest of students of journalism in environmental problems can give the reason for potential to improve public environmental awareness in the Russian Federation. We expect an increase in the number of publications on the discussed topics in both print and electronic media in the near future.

It is well known that, in order to raise public awareness on the issue, it is necessary to provide systematic public information activities. At the same time, preschool and school level education should be the starting point.

Currently, the Russian school educational service provides enough information on environmental issues and greenhouse effects. The conducted analysis of the Russian school textbooks showed that school educational service is actually implementing a public outreach program on the issue coherently (Table 3 ).

Table 3. Results of content analysis of Russian school textbooks.

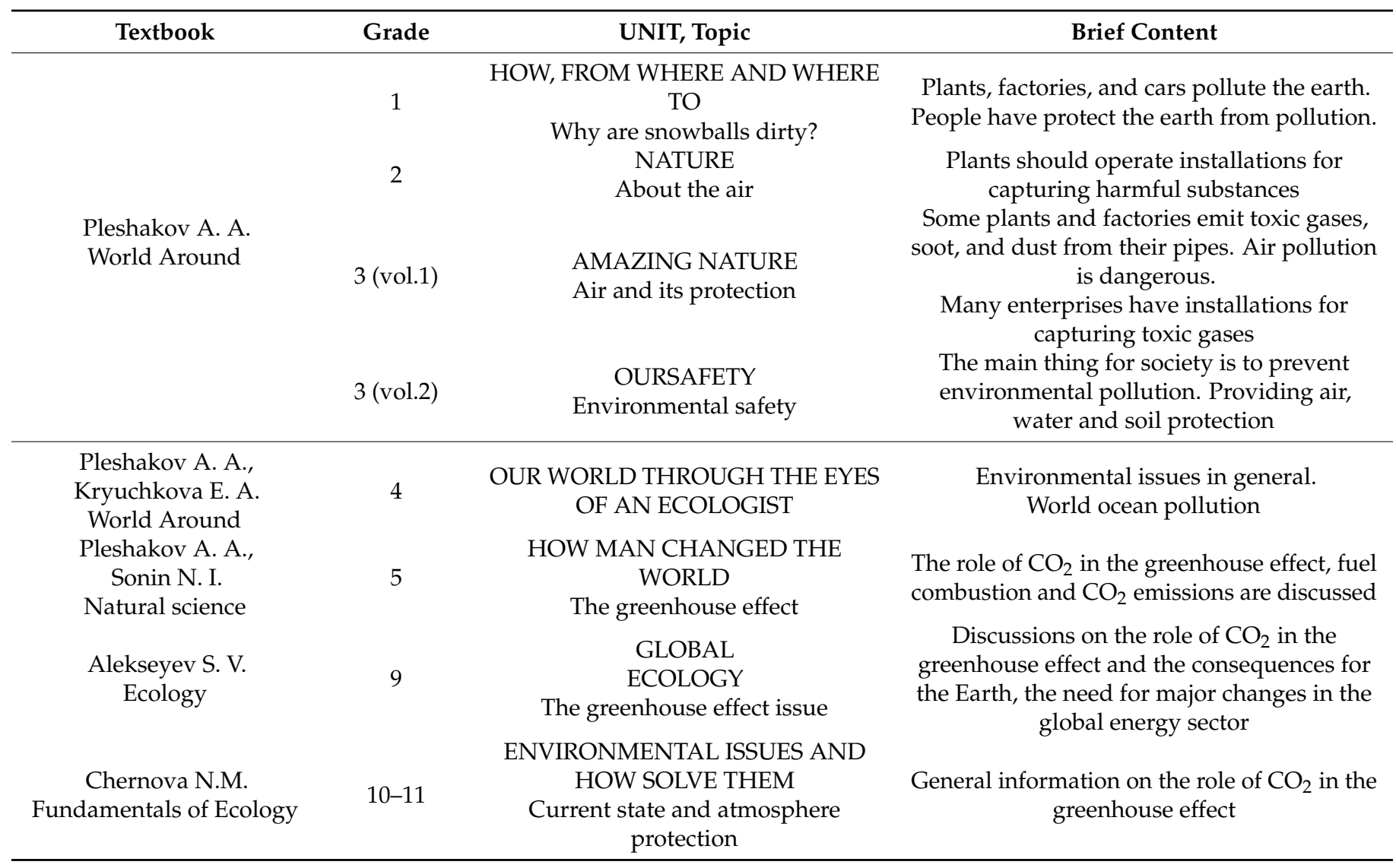

Source: the author's research.

We found out that the ecology textbooks for 6th, 7th, and 8th grades have no information related to the greenhouse effect and $\mathrm{CO}_{2}$ reduction into the atmosphere. Table 3 shows that students of 10th and 11th grades have well-known information studied previously. The information which is included in the ecology textbooks for 5th and 9th grades. In this regard, it can be recommended to include the information 
that would cover the issue in more details in the ecology textbook for 10th and 11th grades. For instance, it could be proposed an overview of technologies contributing $\mathrm{CO}_{2}$ reduction and highlighting CCS technologies.

Not only preschool, school and student audiences should be covered in order to raise public awareness on CCS technologies in Russia. A number of educational guidelines and toolkits for middle and elderly age people should be proposed too.

It would be efficient to post short documentaries for adults on Russian video hosting and Russian social networks on topics related to eliminating the risk of global warming with $\mathrm{CCS}$ technologies. They can be regarded as introductory education to highlight the dangers of $\mathrm{CO}_{2}$ emissions for climate change, and show the global experience of implementing CCS technologies. Production of epatage and shocking documentaries will have a stimulating and motivating effect to increase memorability and attract more public attention to the issues of global warming and climate change. The final part of such documentaries should demonstrate CCS technologies as an efficient tool for reducing global warming risk. They can be broadcast on national television.

While studying YouTube videos on the topic of "Carbon capture and storage", we found more than 300 documentaries and videos dedicated to both CCS technologies and CCS projects implementation. All video materials are produced abroad and broadcast in foreign languages, mainly in English. Thus, in order to increase Russian public awareness on CCS technologies via international video hosting, they should be translated into Russian.

Currently the social networks Vkontakte, Facebook, and Odnoklassniki contain insufficient information on the topics related to $\mathrm{CO}_{2}$ reduction. The study results show that there is some potential for further development in this field (Table 4).

Table 4. Quantity of videos and social media groups on carbon, carbondioxide, GHG.

\begin{tabular}{ccc}
\hline Network & Number of Videos & Social Media Groups \\
\hline Vkontakte & $>30$ & 4 \\
Facebook & 50 & 3 \\
Odnoklassniki & $>60$ & 3 \\
Instagram & - & 8 \\
\hline
\end{tabular}

Source: the author's research.

We searched the social networks using such requests as "carbon", "carbondioxide", "carbondioxide emissions", " $\mathrm{CO}_{2}$ ", “ $\mathrm{GHG}$ ", " $\mathrm{CO}_{2}$ storage", " $\mathrm{CO}_{2}$ reduction", “ $\mathrm{CO}_{2}$ capture", "CO 2 emissions".

Our search requests for videos and social groups with the keywords "CO2 capture", " $\mathrm{CO}_{2}$ storage", " $\mathrm{CO}_{2}$ reduction", “ $\mathrm{CO}_{2}$ emission", "CCS technologies" were not successful.

The conducted content analysis of publications in the most rated Russian newspapers showed that 14 Russian newspapers published 525 articles on climate issues and $\mathrm{CO}_{2}$ reduction inthe past 10 years. The number of publications has positive dynamics. However, only 7 publications in 5 newspapers are devoted to CCS technologies. That is $1.3 \%$ of the entire volume of papers on climate issues and $\mathrm{CO}_{2}$ reduction [48].

The above suggests that there is an urgent need for building communication system of print media on climate change in general, and promoting CCS technologies, in particular. However, it should be stressed that increased number of publications in print media in the future will provide improving environmental awareness among middle and elderly aged people.

For raising Russian public awareness on CCS technologies at the level of preschool and school education the following activities can be proposed:

- organizing training workshops and practical activities on topics related to the circulation and need to capture greenhouse gases, including carbon dioxide;

- providing information on GHG, environmental problems caused by GHG and the ways of their solution in various publications for children (books, encyclopedias); 
- carrying out experimental laboratory works on various rocks permeability, as well as $\mathrm{CO}_{2}$ capture from gas drinks at ecology and chemistry school lessons.

The key factor for preschool and school education is to provide popular children's science publications on topics related to global warming and how prevent it, etc. In this regard it could be useful to follow overseas experience confirming the popularity of children's publications covering the topic of climate change and need for $\mathrm{CO}_{2}$ reduction. Children often get highly interested in publications written by children as, for instance, was done in Australia [21].

The experience of Japan can be recommended for strengthening public perception on CCS. In the framework of the CCS project Tomakomai they published series of comics for children and adults "Let's save the Earth with Cap" [49]. Australia developed the program "Sustainable Futures-CarbonKids" aimed at raising schoolchildren's awareness of $\mathrm{CO}_{2}$ capture and storage projects [21].

Unfortunately, comics are not popular educational tool for the Russian society as they are considered to be means of entertainment for young people [50]. However, eco-comics have good potential for science communication as they are light educational toolkits. Thus, we recommend the publishing of a series of comics on the topics related to global warming risks and measures, and the development of methods to reduce $\mathrm{CO}_{2}$ emissions. The comics should be focused on preschool and school children, as well as university students. We can suggest super-hero comics with Carbon as a villain main character. For example, he can be depicted with a large sign " $\mathrm{CO}_{2}$ ". According to the plot, the villain is captured and disposed, but every time he manages to break free to do some life-threatening and environmental harm. The environmentalist heroes have to struggle with Carbon and settle environmental footprints. Finally, Carbon is caught again and trapped.

Comics with the described plot can be published in children's and youth magazines tailored for specific topics (Quantic, Luchik, Young Naturalist, Young Erudite, GEOlenok, etc.) and general purposes (Murzilka, Chitayka, PoniMashka, Ezhik, Tramvai, Detskaya romangazeta, Luntic, etc).

In addition to the above, it could be also recommended to change the educational programs of academic disciplines at university level. The syllabuses in the disciplines "Ecology", "Ecology of Megacities", "Environmental Safety Systems", and "Waste Management of Production and Consumption" should include topics of lectures and training workshops on the issues of reducing greenhouse gas emissions. In Russian technical universities, the academic discipline "Chemistry" should include practical training on chemical technologies of carbon dioxide capture. Furthermore, students of humanitarian and economic profiles should also have environmental courses integrated into academic curriculum. Such academic disciplines as "Project Management", "Project Implementation Management", and "Innovation Project Management" should be aimed at studying the features of CCS projects currently operating across the world.

To reach the target audience of preschool and school children at a larger scale, a series of cartoon films with the similar plot to eco-comics can also be efficient tool. These cartoons should be included in the programs of children's television channels, and put online. It is necessary to create separate episodes of popular children's animated series: "Fixiki", "Novatory", "Barboskiny", "Bumazhki", "Luntik", "Masha i medved", "Mi-mimishki", "Smeshariki", "Tri kota", and "Monsiki", etc. Some Russian cartoon series depict environmental issues. For example, there is an episode in the animated series "Barboskiny" devoted to separate waste collection.

We draw the attention to the positive experience of the Colgate company, which posted on the Internet a series of cartoons "Dr. Hare and the Legend of the Tooth Kingdom", popularizing teeth brushing and cavity prevention among preschool and primary school children.

For secondary-and-senior-school-age children and university students, it is necessary to make educational documentaries or video tutorials on the topics "Carbon on Earth", "Carbon Issues", and "Catch Carbon." These movies need to be shown in the training course 
of such school subjects as "World Around", "Natural study", "Fundamentals of Ecology", and "Ecology". Watching and discussing video environmental tutorials should become an integrating part of such university training courses as "Ecology", "Fundamentals of Ecology", and "Ecology of Megacities", etc.

Besides this, video tutorials should be posted on YouTube and social networks.

We can propose the children's television channels Carousel and Disney to include environmental videos in the programs (Table 5).

Table 5. Description of the most popular children's TV channels broadcast in the Russian Federation.

\begin{tabular}{|c|c|}
\hline Channel's Name & Channel's Description \\
\hline Carousel & $\begin{array}{l}\text { It is the most popular } 24 \mathrm{~h} \text { television channel. Its content is constantly approved by } \\
\text { psychologists and educators. Cartoons, educational projects, quizzes make up most of the } \\
\text { channel's broadcasting }\end{array}$ \\
\hline Disney & $\begin{array}{c}\text { The broadcasting channel network provides both entertainment and educational programs, } \\
\text { cartoons, TV shows for children and adolescents }\end{array}$ \\
\hline Detskiymir & $\begin{array}{l}\text { It is the first children's television channel in Russia. The program includes cartoons, animated } \\
\text { series, children's television comedies and adventure films. The channel broadcasts both Russian } \\
\text { and foreign programs }\end{array}$ \\
\hline Multimaniya & $\begin{array}{c}\text { TV channel for children aged 3-6 years. It contains educational programs, feature films, } \\
\text { animated series }\end{array}$ \\
\hline $\begin{array}{l}\text { Detskiy } \\
\text { Nickelodeon Russia }\end{array}$ & $\begin{array}{l}\text { The channel produces educational videos on various topics for children aged } 6 \text { to } 12 \text { years old. } \\
\text { The channel broadcasts entertainment programs for children from } 2 \text { to } 6 \text { years old }\end{array}$ \\
\hline Teen-TV & $\begin{array}{l}\text { It is a } 24 \mathrm{~h} \text { channel for teenagers. It contains educational programs such as talk shows, } \\
\text { programs for girls, various educational and entertainment programs }\end{array}$ \\
\hline
\end{tabular}

Source: designed by the authors.

For spreading information on CCS technologies in social networks, it should be recommended to organize a group on $\mathrm{CO}_{2}$ Sequestration to discuss issues of carbon dioxide reduction, global experience of CCS projects development and deployment, etc. Undoubtedly, all video materials should be posted on VKontakte and the other social networks to target the audience.

Besides the mentioned measures, our state authorities should provide national activities to inform the public on need for $\mathrm{CO}_{2}$ reduction and $\mathrm{CCS}$ technologies implementation.

It can be proposed to create regional Internet portals for promoting activities on $\mathrm{CO}_{2}$ emissions reduction in the Russian Federation. The portal should provide a visual presentation of the enterprise potential to reduce $\mathrm{CO}_{2}$ emissions. Gradual introduction of such portals is possible to maintain in the same way as the regional investment standard has been implemented since 2012 in the Russian Federation. Since that time the pilot investment portals were made in 11 regions. Currently the most perspective regions in terms of CCS projects implementation are [2,51,52]:

- Republic of Bashkortostan (Ufa, Sterlitamak, Salavat, Kumertau);

- Republic of Tatarstan;

- Samara region;

- Tyumen region (Tyumen region, KhMAO, YaNAO);

- Kuzbass (Kemerovo region).

In the listed regions pilot carbon portals (web-portals) are to be made in the Russian and English languages in the near future. They are aimed at spreading information on CCS technologies on the regional level. It must be emphasized that carbon portals introduction is a new challenge for the Russian society as presently there are no CCS projects in the territory of the Russian Federation even at the early planning stage.

The proposed guidelines and toolkits can be fundamental principles for building educational system to promote CCS technologies (Figure 4). 


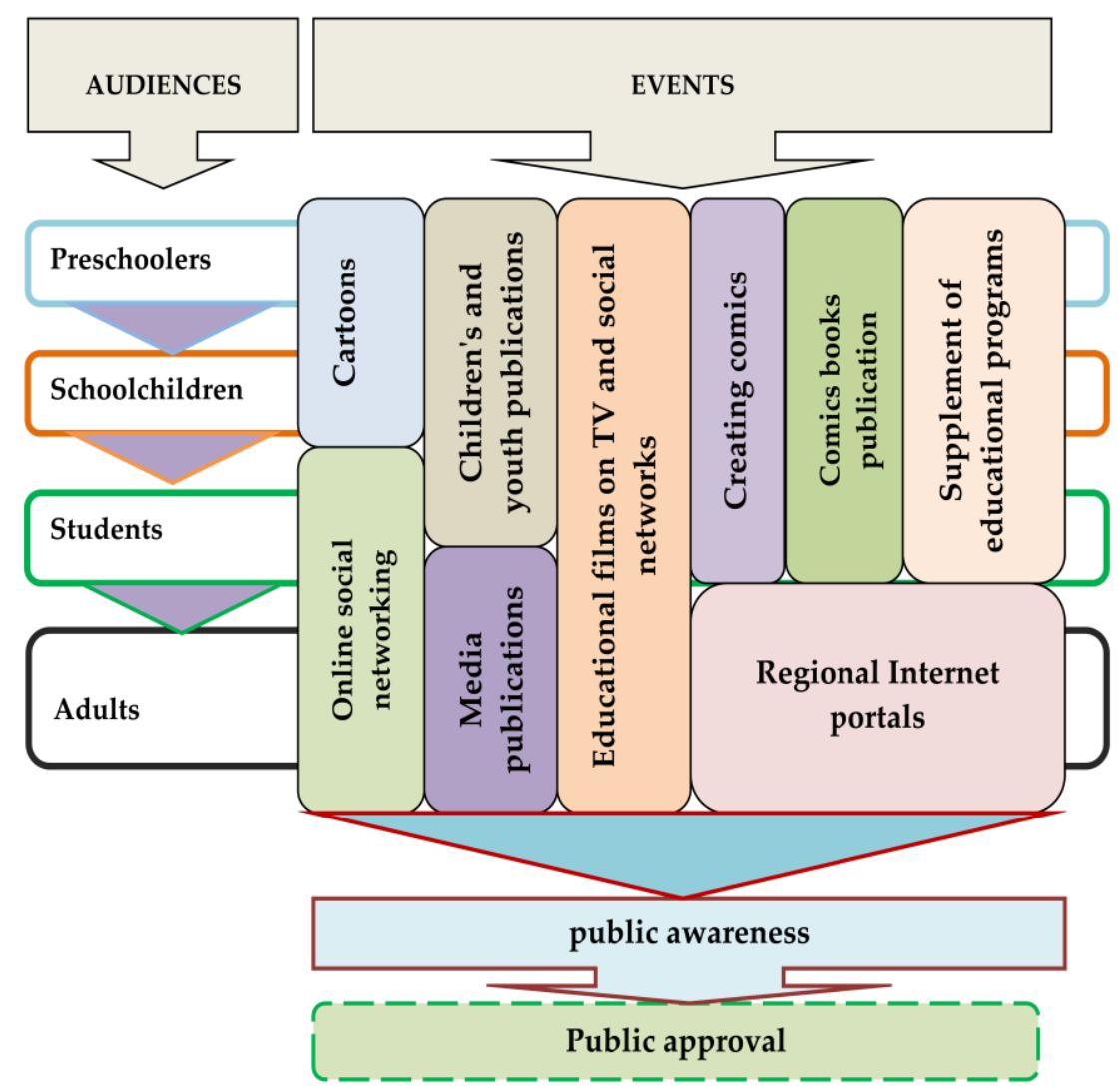

Figure 4. A system of educational and awareness-raising activities for the accumulation of knowledge about $\mathrm{CO}_{2}$ sequestration technologies.

The proposed system of educational and awareness-raising activities allows us to have a comprehensive influence on the society to shape knowledge on carbon capture and storage technologies. As it can be seen from Figure 4, each age group is exposed to a complex effect resulting in getting sustainable knowledge from early childhood.

At the same time, it is noteworthy that all age groups should be informed according to their age interests using appropriate media source.

\section{Conclusions}

The main purpose of the paper is to propose activities for raising public awareness on carbon dioxide capture and storage technologies in the Russian Federation. In this regard, we conducted a number of studies and obtained some results. The analysis of the popularity degree of different types of mass media among Russian students to produce guidelines for forming national educational tools is carried out. An experimental case study introducing environmental component to the English for the Media course was conducted at St Petersburg University (School of Journalism and Mass Communications). A content analysis of school textbooks was carried out to identify the lack of information on reducing greenhouse gases emissions technologies. A secondary study of newspaper articles published in the Russian Federation over 10 years was introduced. The materials of the YouTube video hosting were examined by the request of "Carbon capture and storage" to find related videos.

Particularly, we revealed a low degree of information spreading on CCS technologies in the social media. We introduced the potential of information spreading among preschoolers and schoolchildren. The most popular sources of information among students were identified. A system of educational and awareness-raising activities for accumulating knowledge about CCS technologies in the Russian Federation is proposed. 
The implementation of the above-mentioned activities for building communication system regarding the development of CCS technologies requires certain investments. Such investments should be carried out by the state. At the same time, energy and mining companies can also provide investments in the most suitable regions for implementing CCS projects.

Author Contributions: Conceptualization, A.C.; methodology, A.C., A.T., Y.V., and N.K.; investigation, Y.V., A.T.; resources, A.C., Y.V.; writing—original draft preparation, A.C., A.T., Y.V., and N.K.; writing - review and editing, Y.V., N.K. All authors have read and agreed to the published version of the manuscript.

Funding: This research received no external funding.

Institutional Review Board Statement: Not applicable.

Informed Consent Statement: Informed consent was obtained from all subjects involved in the study.

Data Availability Statement: Not applicable.

Conflicts of Interest: The authors declare no conflict of interest.

\section{References}

1. Ilinova, A.A.; Romasheva, N.V.; Stroykov, G.A. Prospects and social effects of carbon dioxide sequestration and utilization projects. J. Min. Inst. 2020, 244, 493-502. [CrossRef]

2. Khlebnikov, V.N.; Zobov, P.M.; Hamidullin, I.R.; Ruzanova, Y.F.; Ivanov, E.V.; Vinokurov, V.A. Perspective regions for implementation of projects on storage of greenhouse gases in Russia. Bashkir Chem. J. 2009, 16, 73-80.

3. Carbon Capture: A Technology Assessment. Available online: https://fas.org/sgp/crs/misc/R41325.pdf (accessed on 16 February 2021).

4. Intergovernmental Panel on Climate Change (IPCC), IPCC Special Report on Carbon Dioxide Capture and Storage. Prepared by Working Group III of the Intergovernmental Panel on Climate Change. Available online: https:/ / www.opec.org/opec_web/ static_files_project/media/downloads/press_room/Leo_Meyer_-_Presentation.pdf (accessed on 16 February 2021).

5. IPCC Special Report. Carbon Dioxide Capture and Storage: Technical Summary. Available online: https:// docplayer.net/204370 54-Ipcc-special-report-carbon-dioxide-capture-and-storage-technical-summary.html (accessed on 16 February 2021).

6. What Is Carbon Capture and Storage (CCS)? Available online: https://ccsknowledge.com/what-is-ccs (accessed on 19 August 2020).

7. Gaurina-Međimurec, N.; Novak Mavar, K.; Majić, M. Carbon capture and storage (CCS): Technology, projects and monitoring review. Min.-Geol.-Pet. Eng. Bull. 2018, 33, 1-15.

8. CTCN. CO2 Capture Technologies. Available online: https:/ /www.ctc-n.org/technologies/co2-capture-technologies (accessed on 11 November 2020).

9. Kim, Y.; Jang, H.; Kim, J.; Lee, J. Prediction of storage efficiency on $\mathrm{CO}_{2}$ sequestration in deep saline aquifers using artificial neural network. Appl. Energy 2017, 185, 916-928. [CrossRef]

10. Theo, W.L.; Lim, J.S.; Hashim, H.; Mustaffa, A.A.; Ho, W.S. Review of pre-combustion capture and ionic liquid in carbon capture and storage. Appl. Energy 2016, 183, 1633-1663. [CrossRef]

11. International Energy Agency. Carbon Capture \& Storage: The Solution for Deep Emissions Reductions. Available online: https: //ru.scribd.com/document/303671312/Carbon-Capture-and-Storage-the-Solution-for-Deep-Emissions-Reductions (accessed on 17 February 2021).

12. Global Status of CCS: Brief for Policymakers. Global Carbon Capture and Storage Institute Ltd. 2019. Available online: https://www. globalccsinstitute.com/wp-content/uploads/2020/03/11204-GCC_GLOBAL2019-STATUS-REPORT_ES_PRINT_Digital-1.pdf (accessed on 28 August 2020).

13. The Global Status of CCS: 2016 Summary Report. Global CCS Institute. 2016. Available online: http:/ /www.ccop.or.th/ccsm/ data/31/docs/GCCSI-keynote-S6.pptx.pdf (accessed on 5 November 2018).

14. Feldpausch-Parker, A.; Burnham, M.; Melnik, M.; Callaghan, M.L.; Selfa, T. News Media Analysis of Carbon Capture and Storage and Biomass: Perceptions and Possibilities. Energies 2015, 8, 3058-3074. [CrossRef]

15. Gough, C.; Cunningham, R.; Mander, S. Societal responces to $\mathrm{CO}_{2}$ storage in the UK: Media, stakeholder and public perspectives. Energy Procedia 2017, 114, 7310-7316. [CrossRef]

16. Dowd, A.-M.; James, M. A Social Licence for Carbon Dioxide Capture and Storage: How Engineers and Managers Describe Community Relations. Soc. Epistemol. 2014, 28, 364-384. [CrossRef]

17. Ferguson, B.; Van Gent, D. A multi-level, multi-platform approach to communications on the South West Hub CCS project. Energy Procedia 2017, 114, 7260-7275. [CrossRef]

18. Brunsting, S.; de Best-Waldhober, M.; Terwel, B.W. Why more knowledge about $\mathrm{CO}_{2}$ storage hardly improves public attitudes. J. Energy Procedia 2013, 37, 7419-7427. [CrossRef] 
19. Arning, K.; Offermann-van Heek, J.; Linzenich, A.; Kaetelhoen, A.; Sternberg, A.; Bardow, A.; Ziefle, M. Same or different? Insights on public perception and acceptance of carbon capture and storage or utilization in Germany. Int. J. Energy Pol. 2019, 125, 235-249. [CrossRef]

20. Ashworth, P.; Wade, S.; Reiner, D.; Liang, X. Developments in public communications on CCS. Int. J. Greenh. Gas Control 2015, 40, 449-458. [CrossRef]

21. Bloxsome, B.; Van Gent, D.; Stalker, L.; Ferguson, B. A collaborative approach to school community engagement with a local CCS project. Energy Procedia 2017, 114, 7295-7309. [CrossRef]

22. Boyd, A.D.; Hmielowski, J.D.; David, P. Public perceptions of carbon capture and storage in Canada: Results of a national survey. Int. J. Greenh. Gas Control 2017, 67, 1-9. [CrossRef]

23. Jones, C.R.; Gaede, J.; Ganovski, S.; Rowlands, I.H. Understanding lay-public perceptions of energy storage technologies: Results of a questionnaire conducted in the UK. In Proceedings of the 3rd Annual Conference in Energy Storage and Its Applications, Sheffield, UK, 11-12 September 2018; Volume 151, pp. 135-143.

24. Mulyasari, F.; Nur Ahadi, M.; Harahap, A.K.; Lestari, P.; Ahmad, P.; Sungkowo, A.; Triwardani, R.; Yogafanny, E.; Utami, A.; Setyowati, R.; et al. Preliminary Public engagement plan and typology of communication dynamics for CCS Gundih Pilot Project in Indonesia. In Proceedings of the 14th International Conference on Greenhouse Gas Control Technologies, Melbourne, Australia, 21-25 October 2018; pp. 5116-5127.

25. Sacuta, N.; Daly, D.; Botnen, B.; Worth, K. Communicating about the geological storage of carbon dioxide-Comparing public outreach for $\mathrm{CO}_{2}$ EOR and saline storage projects. Energy Procedia 2017, 114, 7245-7259. [CrossRef]

26. Saito, A.; Itayoka, K.; Akai, M. Those who care CCS—Results from Japanese Survey on Public Understanding of CCS. In Proceedings of the 14th International Conference on Greenhouse Gas Control Technologies, Melbourne, Australia, 21-25 October 2018; pp. 5104-5115.

27. Schäfer, M. From Public Understanding to Public Engagement an Empirical Assessment of Changes in Science Coverage. Sci. Commun. 2009, 30, 475-505. [CrossRef]

28. Shcherbinina, E.A. Environmental problems in the mass media of the Chelyabinsk region (on the example of the network publication "Province-southern Urals"). Mediasreda 2017, 12, 316-320.

29. Vercelli, S.; Lombardi, S.; Modesti, F.; Tartarello, M.; Finoia, M.; De Angelis, D.; Bigi, S.; Ruggiero, L.; Pirrotta, S. Making the communication of CCS more "human". Energy Procedia 2017, 114, 7367-7378. [CrossRef]

30. Keane, R. Communication about Carbon Capture and Storage through social media. In Proceedings of the 14th International Conference on Greenhouse Gas Control Technologies, Melbourne, Australia, 21-25 October 2018; pp. 5128-5140.

31. Mander, S.; Canningham, R.; Lever, L.; Gough, K. Comparing online and offline knowledge networks of Carbon Capture and Storage. Energy Procedia 2017, 114, 7326-7332. [CrossRef]

32. Kubota, H.; Shimota, A. How should information about CCS be shared with the Japanese public? Energy Procedia 2017, 114, 7205-7211. [CrossRef]

33. Li, Q.; Liu, G.; Leamon, G.; Liu, L.; Cai, B.; Chen, Z. A national survey of public awareness of the environmental impact and management of CCUS technology in China. Energy Procedia 2017, 114, 7237-7244. [CrossRef]

34. Anghel, S. Impact of CCS communication on the general and local public in Romania- Oltenia region. Energy Procedia 2017, 114, 7310-7316. [CrossRef]

35. Itaoka, K.; Saito, A.; Paukovic, M.; de Best-Waldhober, M.; Dowd, A.; Jeanneret, T.; Ashworth, P.; James, M. Understanding How Individuals Perceive Carbon Dioxid: Implications for Acceptance of Carbon Dioxide Capture and Storage; CSIRO Report EP 118160; CSIRO: Canberra, Australia, 2012; 98p.

36. Fedoseev, S.V.; Tcvetkov, P.S. Key factors of public perception of carbon dioxide capture and storage projects. J. Min. Inst. 2019, 237, 361-368. [CrossRef]

37. Chvileva, T.A.; Ilinova, A.A. Features of interaction with stakeholders in the implementation of carbon sequestration projects. Russ. Econ. Online Mag. 2018, 4, 117-125.

38. The Economist (USA): Why Is Russia So Ambivalent about Global Warming? Available online: https://inosmi.ru/social/201909 18/245844873.html (accessed on 17 February 2021).

39. Anisimov, O.A.; Kokorev, V.A. Climate in the Arctic zone of Russia: Analysis of current changes and modeling trends for the 21st century. Mosc. Univ. Bull. 2016, 5, 61-70.

40. Romasheva, N.V.; Kablan, I.B.K. Foreign experience in regulatory regulation of carbon dioxide capture and disposal projects. Econ. Entrep. 2019, 9, 864-868.

41. Nevskaya, M.A.; Marinina, O.A. Challenges and opportunities of state regulation of the innovation process in the Russian mineral resources sector. Acad. Strateg. Manag. J. 2017, 16, 149-159.

42. Marinina, O. Analysis of trends and performance of CSR mining companies. IOP Conf. Ser. Earth Environ. Sci. 2019, 302, 012120. [CrossRef]

43. Vasilenko, N.; Khaykin, M.; Kirsanova, N.; Lapinskas, A.; Makhova, L. Issues for development of economic system for subsurface resource management in Russia through lens of economic process servitization. Int. J. Energy Econ. Policy 2019, 10, 44-48. [CrossRef]

44. Cherepovitsyn, A.; Chvileva, T.; Fedoseev, S. Popularization of Carbon Capture and Storage Technology in Society: Principles and Methods. In. J. Environ. Res. Public Health 2020, 17, 8368. [CrossRef] [PubMed] 
45. Telegina, E.A.; Tyrtyshova, D.O. Natural gas in the context of decarbonisation of the European energy market: Constraints and adaptation measures. Oil Gas Bus. 2017, 11, 38-43.

46. Media Consumption in Russia-2018; Research Center of "Deloit" Company in UIS: Moscow, Russia, 2018; 50p, Available online: https:/ / www2.deloitte.com/ru/ru.html (accessed on 22 January 2021).

47. VTsIOM: Most Russians Prefer to Read Newspapers and Magazines in Paper Form. Available online: https://tass.ru/obschestvo/ 1691624 (accessed on 22 January 2021).

48. Vasilev, Y.; Vasileva, P.; Tsvetkova, A. The study of spreading information on CCS and CCUS technologies in the social media. In Proceedings of the International Multidisciplinary Scientific GeoConference Surveying Geology and Mining Ecology Management, SGEM, Sofia, Bulgaria, 18-24 August 2020; pp. 833-839. [CrossRef]

49. Let's Save the Earth with Cap. Available online: https://www.japanccs.com/wp/wp-content/uploads/2018/11/CCS_manga_ En_web_1607293.pdf (accessed on 17 February 2021).

50. Nevsky, B.; Serebryansky, S. Russia Has not yet Become a Comics Country. Interview with the Editor-in-Chief of Azbuka. Available online: https:/ / www.mirf.ru/comics/intervyu-s-glavnym-redaktorom-azbuki (accessed on 22 January 2021).

51. Kirsanova, N.Y.; Lenkovets, O.M.; Nikulina, A.Y. The role and future outlook for renewable energy in the Arctic zone of Russian Federation. Eur. Res. Stud. J. 2018, 21, 356-368.

52. Gasumov, R.A.; Gasumov, E.R.; Minchenko, J.S. Features of the underground storages construction in depleted oil and gas condensate fields. J. Min. Inst. 2020, 244, 418-427. [CrossRef] 